\title{
Electrochemical reduction of oxygen and nitric oxide at low temperature on La1xSrxMnO3+ cathodes
}

\section{Kammer Hansen, Kent}

Published in:

Materials Research Bulletin

Link to article, DOI:

10.1016/j.materresbull.2013.05.029

Publication date:

2013

Link back to DTU Orbit

Citation (APA):

Kammer Hansen, K. (2013). Electrochemical reduction of oxygen and nitric oxide at low temperature on $\mathrm{La} \mathrm{Sr}_{\mathrm{MnO}}$ cathodes. Materials Research Bulletin, 48(9), 3274-3277.

https://đoi.org/†0.1016/j.materresbull.2013.05.029

\section{General rights}

Copyright and moral rights for the publications made accessible in the public portal are retained by the authors and/or other copyright owners and it is a condition of accessing publications that users recognise and abide by the legal requirements associated with these rights.

- Users may download and print one copy of any publication from the public portal for the purpose of private study or research.

- You may not further distribute the material or use it for any profit-making activity or commercial gain

- You may freely distribute the URL identifying the publication in the public portal

If you believe that this document breaches copyright please contact us providing details, and we will remove access to the work immediately and investigate your claim. 
Electrochemical Reduction of Oxygen and Nitric oxide at low Temperature on $\mathrm{La}_{1-x} \mathrm{Sr}_{x} \mathrm{MnO}_{3+\delta}$ Cathodes.

K. Kammer Hansen

Department of Energy conversion and Storage

Technical University of Denmark

Frederiksborgvej 399

DK-4000 Roskilde, Denmark

e-mail: kkha@dtu.dk

phone: 4546775835

fax: 4546775858

Keywords: NO; $\mathrm{O}_{2}$; LSM; CGO; Flue gas; Cathode 
Abstract: $\operatorname{Six} \mathrm{La}_{1-x} \mathrm{Sr}_{x} \mathrm{MnO}_{3+\delta}(x=0,0.05,0.15,0.25,0.35,0.50)$ perovskites were synthesised and characterised by powder XRD and cyclic voltammetry on cone-shaped electrodes in $10 \%$ oxygen in argon or $1 \%$ nitric oxide in argon at 200,300 and $400{ }^{\circ} \mathrm{C}$. The activity of the manganite based perovskites were highest in the nitric oxide containing atmosphere compared to the activity in the oxygen containing atmosphere at $200{ }^{\circ} \mathrm{C}$. At 300 and $400{ }^{\circ} \mathrm{C}$ the activity in the nitric oxide and oxygen containing atmospheres were similar. The highest ratio between the cathodic current densities in the nitric oxide and oxygen containing atmospheres was found for the $\mathrm{La}_{0.95} \mathrm{Sr}_{0.05} \mathrm{MnO}_{3+\delta}$ perovskite at 200 ${ }^{\circ} \mathrm{C}$.

Introduction: Pollutants emitted from the combustion of fossil fuels is an increasing problem, especially in urban areas. The main pollutants emitted are particulate matter, hydrocarbons, $\mathrm{CO}$ and $\mathrm{NO}_{\mathrm{x}}[1]$. Whereas the three-way catalytic converter can remove hydrocarbons, $\mathrm{CO}$ and $\mathrm{NO}_{\mathrm{x}}$ from the exhaust from petrol fired Otto engines, the three-way catalytic converter is not able to remove $\mathrm{NO}_{\mathrm{x}}$ from the exhaust emitted from Diesel fired engines, due to the excess of oxygen in the exhaust $[2,3]$. Other methods for removal of $\mathrm{NO}_{\mathrm{x}}$ from the exhaust from Diesel fired engines therefore have to be developed. The concept used at present is the selective catalytic reduction (SCR) of $\mathrm{NO}_{\mathrm{x}}$. Here a reducing agent is added to the exhaust stream, and brought to react with the $\mathrm{NO}_{\mathrm{x}}$ on a suitable catalyst [4]. The main problems with this technique are the need of storage of the reducing agent on board the vehicle and possible slip of the reducing agent. Another approach is to use an all solid state electrochemical cell, as suggested by Pancharatnam et al. [5]. The advantage of the electrochemical approach is that no reducing agent is needed. This technique is, however, still in its embryonic state. The main obstacles are a low current efficiency due to simultaneously reduction of oxygen at the 
cathode, and a low activity at the temperatures in the exhaust gas [6]. Only a few electrodes are known to reduce the $\mathrm{NO}_{\mathrm{x}}$ under net oxidising conditions with a sufficient high selectivity $[7,8]$. However, these electrodes are expensive or even poisonous. The search for low cost non poisonous electrodes is therefore on-going. In this study six $\mathrm{La}_{1-x} \mathrm{Sr}_{x} \mathrm{MnO}_{3+\delta}(x=0,0.05,0.15,0.25,0.35,0.50)$, (LSMx) manganites were synthesised and investigated using powder XRD and cyclic voltammetry on cone-shaped electrodes. The use of cone-shaped electrodes, suggested by Fabry and Kleitz [9] are particular useful when comparing different electrode materials, see [10-13] for some examples of the use of this technique. We have before been investigating LSM cathodes for the reduction of nitric oxide and oxygen $[14,15]$, but in this study the reduction of nitric oxide and oxygen is being studied at lower temperatures. LSM perovskites are known to be intrinsic p-type conductors [16]. The low strontium substituted LSM perovskites are unique in the sense that they are over-stoichiometric with respect to oxygen in air [17]. LSM is the classical choice for a cathode in a solid state fuel cell operating at high temperature [18].

Experimental: Synthesis of the manganite based perovskites was done using the glycine-nitrate process [19]. In short the metal nitrates were dissolved in water and mixed in the appropriate ratio. Glycine was then added and the solution was heated on a hot plate until ignition. After this the resulting powder was transferred to an alumina crucible and placed in a box furnace. The powders were calcined at $1000^{\circ} \mathrm{C} / 6 \mathrm{~h}$ in air. The phase purity of the powders was checked using XRD. For the XRD a Stoe theta-theta diffractometer or a Bruker D8 diffractometer was used. Cylinders for the preparation of the cone-shaped electrodes were made by pressing 7-8 g powder in an appropriate die and sinter at $1250{ }^{\circ} \mathrm{C} / 12 \mathrm{~h}$ in air in a box furnace. After sintering the cylinders were machined into 
cone-shaped electrodes using diamond tools. A small disk for use in the XRD was also cut. The electrochemical measurements were done in a set up described elsewhere [20]. The set up is a two atmosphere set up, where the reference/counter electrode is placed in air, and the working electrode (the cone) is placed in either $1 \%$ nitric oxide in argon or $10 \%$ oxygen in argon. The area of the reference/counter electrode is many times larger than the working electrode. The set up is therefore a pseudo three electrode set up. The electrochemical characterisation was done using a Gamry Femtostat potentiostat. The voltammograms were recorded in from $0.4 \mathrm{~V}$ vs. air to $-0.8 \mathrm{~V}$ vs. air, starting at open circuit voltage (OCV) and run in the cathodic potential region first. Voltammograms were recorded with sweep rates 1 and $10 \mathrm{mV} / \mathrm{s}$. The electrodes were equilibrated at OCV for $2 \mathrm{~h}$ before running the scans. Electrochemical impedance spectroscopy (EIS) was also performed in order to find the contact areas of the electrodes using Newman's formula [21].
(1) $r=\frac{1}{4 R_{s} \sigma^{*}}$

Where $\mathbf{R}_{\mathbf{s}}$ is the series resistance and $\sigma$ is the specfic conductivity of the electrolyte. The EIS were recorded from $300 \mathrm{kHz}$ to $0.05 \mathrm{~Hz}$ with 10 points per decade and an amplitude of $25 \mathrm{mV}$ rms. The EIS were recorded at OCV with an equilibration time of $2 \mathrm{~h}$. The electrochemical experiments were done at 200,300 and $400{ }^{\circ} \mathrm{C}$ in either $1 \%$ nitric oxide in argon or $10 \%$ oxygen in argon. The gas flow was controlled by Brooks mass flow controllers.

Results: The results from the XRD show that the synthesised perovskites are single phased. The LSM's could be indexed in either a hexagonal or an orthorhombic unit cell. The unit cell parameters are given in Table 1. Examples of voltammograms are shown in Figs. 1 to 3. As no large difference was 
observed from the voltammograms recorded with sweep rates of 1 and $10 \mathrm{mV} / \mathrm{s}$ only the voltammograms recorded with a sweep rate of $1 \mathrm{mV} / \mathrm{s}$ are shown. The voltammograms recorded in the nitric oxide containing atmosphere at $200{ }^{\circ} \mathrm{C}$ on the LSM05 perovskite reveals a large hysteresis in the cathodic potential regime, see Fig. 1 . This is observed for several of the compounds at $200{ }^{\circ} \mathrm{C}$. At $300{ }^{\circ} \mathrm{C}$ the voltammogram recorded in the nitric oxide containing atmosphere reaches a plateau at approximately $-2 \mathrm{mAcm}^{-2}$, see Fig 2 . This is also observed for several of the compounds. At $400{ }^{\circ} \mathrm{C}$ this behaviour is less pronounced. Current densities at $-0.8 \mathrm{~V}$. vs. air in either the oxygen or the nitric oxide containing atmospheres are given in Table 2 . The maximum current density in the oxygen containing atmosphere is found for the intermediate perovskite LSM25 at $200{ }^{\circ} \mathrm{C}$. At 300 and $400{ }^{\circ} \mathrm{C}$ the end member LSMOO is most active in the oxygen containing atmosphere, although the dependence of composition is very small at $400{ }^{\circ} \mathrm{C}$. The maximum current density in the nitric oxide containing atmosphere at $200{ }^{\circ} \mathrm{C}$ is found for the LSM05 perovskite. At 300 and $400{ }^{\circ} \mathrm{C}$ the $\operatorname{LSM} 15$ perovskite is most active in the nitric oxide containing atmosphere. The larges ratio of the current densities in the oxygen and nitric oxide containing atmospheres is found for the LSM05 perovskite at $200{ }^{\circ} \mathrm{C}$, see Fig. 4. The anodic current densities, at a potential of $0.4 \mathrm{~V}$ vs. air are given in Table 3.

Discussion: The behaviour of the LSM based perovskites is most clear cut at $200{ }^{\circ} \mathrm{C}$. In the nitric oxide containing atmosphere the activity of the manganites decreases when strontium is substituted for lanthanum, with LSMOO as the exception. This indicates that either the redox capacity or the amount of $\mathrm{Mn}(\mathrm{III})$ is determining for the activity of the manganites towards the reduction of nitric oxide, as the redox capacity and the amount of $\mathrm{Mn}(\mathrm{III})$ deceases with increasing strontium content [17]. That LSM00 behaves differently could perhaps be due to that LSM00 do not contain strontium. At $300{ }^{\circ} \mathrm{C}$ 
the trend is almost the same as at $200{ }^{\circ} \mathrm{C}$, but at $400{ }^{\circ} \mathrm{C}$ the trend is markedly different. The increase in activity from LSM00 to LSM05 and LSM15 is perhaps due to that more oxide ion vacancies is formed when strontium is substituted for lanthanum. The decrease from LMS15 to LSM25 could is due to a lowering of the amount of $\mathrm{Mn}(\mathrm{III})$, as it is the case at $200{ }^{\circ} \mathrm{C}$, or perhaps that this compound has a very low redox capacity [17]. That the activity increases from LSM25 to LSM35 and LSM50 could be because the high strontium substituted manganites has some ionic conductivity at $400{ }^{\circ} \mathrm{C}$, leading to a higher activity. However, it is difficult to give a satisfactory explanation for this complex behaviour. In the oxygen containing atmosphere at $200{ }^{\circ} \mathrm{C}$ LSM00 is again an exception, and the maximum cathodic current density is observed for LSM25. This indicates that the reduction of oxygen is less dependent on the $\mathrm{Mn}(\mathrm{III})$ content than for the reduction of nitric oxide, at these very low temperatures. At the higher temperature $300{ }^{\circ} \mathrm{C}$ the trend is almost the same, but at $400{ }^{\circ} \mathrm{C}$ no systematic trend is observed. This could be due to the fact that the differences are quite small, so that the differences are within the experimental uncertainties, which might hide the differences in the properties of the electrodes. The limiting cathodic current density observed for some of the compounds, has also been observed for cobalt based perovskites [22]. This was thought to be due to a rate limiting chemical step in the reaction sequence. The same may be the reason in this case. The large hysteresis observed for LSM05 at $200{ }^{\circ} \mathrm{C}$ in the nitric oxide containing atmosphere could also be due to this limiting current density. That the activation energy for the reduction of oxygen is higher than the activation energy for the reduction of nitric oxide has been observed before [14, 22]. It seems like it is a general feature that the activation energy for the electrochemical reduction of nitric oxide is lower than the activation energy for the reduction oxygen. That the ratio of the current 
densities in the nitric oxide and oxygen containing atmospheres is highest for the LSM05 perovskite makes this compound most interesting as a cathode for electrochemical reduction of nitric oxide. Another general feature is the potential of the initiation of the reduction of nitric oxide. This potential is very low compared to the calculated value (app. $0.5 \mathrm{~V}$ vs. air). This shows that the reaction:

(1) $\mathrm{NO}+2 \mathrm{e}^{-} \leftrightarrows 1 / 2 \mathrm{~N}_{2}+\mathrm{O}^{2-}$,

not is occurring. Instead the OCV is a mixed potential determined by the reduction of nitric oxide, the oxygen evolution and the oxidation of nitric oxide to nitrogen dioxide, i.e. determined by oxygen exchange. The anodic current densities in the nitric oxide and oxygen containing atmospheres follow the trend as for the cathodic current densities in the nitric oxide and oxygen containing atmospheres. This indicates that the same properties are needed in other to oxidise nitric oxide than to reduce nitric oxide. The results in the nitric oxide atmosphere at 300 and $400{ }^{\circ} \mathrm{C}$ confirm to some extend earlier results $[14,15]$. The results at $200{ }^{\circ} \mathrm{C}$ are new and have not been reported before. However, the results in the oxygen containing atmosphere are different. This could be due to that the temperatures used in this study are lower, than the ones used in the literature [15]. It could also be due to a different treatment of the electrolyte. This will be investigated further in an up-coming study.

Conclusion: Oxygen and nitric oxide can be reduced at low temperatures on strontium substituted lanthanum manganites. The manganites are more active towards nitric oxide reduction than towards oxygen reduction at $200{ }^{\circ} \mathrm{C}$. At 300 and $400{ }^{\circ} \mathrm{C}$ the activity towards oxygen and nitric oxide reduction is similar. At the lowest temperature the activity towards the reduction of nitric oxide is mainly 
determined by the redox capacity or the amount of $\mathrm{Mn}(\mathrm{III})$. The reduction of oxygen is less dependent on the amount of $\mathrm{Mn}(\mathrm{III})$.

Acknowledgements: The technical staff at the fuel cells and solid state chemistry division is thanked for help with the preparation of the samples. Financial support from the strategic research council is highly appreciated (contract no. 09-065186).

\section{References:}

[1] G.C. Koltsakis, A.M. Stamatelos, Prog. Energy Combust. Sci., 231 (1997)

[2] K.C. Taylor, in: Frontiers of Materials Research/Electronic and Optical Materials, eds. M. Kong and

L. Huang, (Elsevier, Amsterdam, 1991), p. 46-56

[3] J. Kaspar, P. Fornasiero, N. Hickey, Catal. Today, 77419 (2003)

[4] H. Bosch, F. Janssen, Catal. Today, 2369 (1988)

[5] S. Pancharatnam, R.A. Huggins, D.M. Mason, J. Electrochem. Soc., 122869 (1975)

[6] K. Kammer Hansen, Appl. Catal. B: Environmental, 100427 (2010)

[7] K. Iwayama, X. Wang, Appl. Catal. B: Environmental, 19137 (1998)

[8] K. Hamamoto, Y. Fujishiro, M. Awano, J. Electrochem. Soc., 155 E109 (2008)

[9] P. Fabry, M Kleitz, Electroanal. Chem. Interfac., Electrochem., 57, 165 (1974)

[10] K. Kammer, E.M. Skou, Solid State lonics, 176915 (2005)

[11] K. Kammer, M. Mogensen, Electrochem. Solid-State Lett., 8 A108 (2005)

[12] K. Kammer, Solid State lonics, 1771047 (2006)

[13] K.K. Hansen, K.V. Hansen, Solid State lonics, 1781379 (2007)

[14] K. Kammer Hansen, E.M. Skou, H. Christensen, J. Electrochem. Soc., 1472007 (2000) 
[15] K. Kammer Hansen, H. Christensen, E.M. Skou, Ionics, 6340 (2000)

[16] J. Mizusaki, Y. Yonemura, H. Kamata, O. Kouji, M. Naoya, T. Hiroshi, T. Hiroaki, D. Masayuki, N. Kazunori, S. Tadashi, I. Hideaki, H. Takuya, Solid State Ionics, 132167 (2000)

[17] I.G. Krogh Andersen, E. Krogh Andersen, P. Norby, E. Skou, J. Solid State Chem., 113320 (1994)

[18] N.Q. Minh, T. Takahashi, 'Science and technology of ceramic fuel cells', Elsevier Science B.V.

[19] L.A. Chick, L.R. Pederson, G.D. Maupin, J.L. Bates, L.E. Thomas, G.J. Exarhos, Mat. Lett., 106 (1990)

[20] K. Kammer Hansen, H. Christensen, E.M. Skou, S.V. Skaarup, J. Appl. Electrochem., 30193 (2000)

[21] J. Newman, J. Electrochem. Soc., 113501 (1966)

[22] K. Kammer Hansen, J. Electrochem. Soc., 157 P79 (2010) 


\section{Table captions:}

Table 1. The unit cell parameters for the LSM compounds in air at room temperature, measured on sintered pellets.

Table 2. Maximum cathodic current densities in either $1 \%$ nitric oxide in argon or $10 \%$ oxygen in argon on LSM based cathodes at $-0.8 \mathrm{~V}$ vs. air at 200,300 and $400{ }^{\circ} \mathrm{C}$. The current densities are numerical values given in $\mathrm{mAcm}^{-2}$.

Table 3. Maximum anodic current densities in either nitric oxide in argon or $10 \%$ oxygen in argon on LSM based cathodes at $0.4 \mathrm{~V}$ vs. air at $200{ }^{\circ} \mathrm{C}$. The current densities are given in $\mathrm{mAcm}^{-2}$. 
Table 1.

\begin{tabular}{|c|c|c|c|c|c|c|}
\hline & LSM00 & LSM05 & LSM15 & LSM25 & LSM35 & LSM50 \\
\hline $\mathrm{A} / \AA$ & $7.706(8)$ & $7.745(5)$ & $5.5157(16)$ & $5.5271(13)$ & $5.4960(13)$ & $7.709(3)$ \\
\hline $\mathrm{B} / \AA$ & $5.628(3)$ & $5.5843(20)$ & - & - & - & $5.614(4)$ \\
\hline $\mathrm{C} / \AA$ & $5.530(3)$ & $5.5485(24)$ & $13.343(14)$ & $13.361(11)$ & $13.356(3)$ & $5.4540(21)$ \\
\hline
\end{tabular}

Table 2.

\begin{tabular}{|c|c|c|c|c|c|c|c|c|c|c|c|c|}
\hline compound & \multicolumn{2}{|c|}{ LSM00 } & \multicolumn{2}{c|}{ LSM05 } & \multicolumn{2}{c|}{ LSM15 } & \multicolumn{2}{c|}{ LSM25 } & \multicolumn{2}{c|}{ LSM35 } & \multicolumn{2}{c|}{ LSM50 } \\
\hline T/Gas & $\mathrm{O}_{2}$ & $\mathrm{NO}$ & $\mathrm{O}_{2}$ & $\mathrm{NO}$ & $\mathrm{O}_{2}$ & $\mathrm{NO}$ & $\mathrm{O}_{2}$ & $\mathrm{NO}$ & $\mathrm{O}_{2}$ & $\mathrm{NO}$ & $\mathrm{O}_{2}$ & $\mathrm{NO}$ \\
\hline $200^{\circ} \mathrm{C}$ & 0.0095 & 0.23 & 0.0045 & 0.58 & 0.0096 & 0.22 & 0.03 & 0.11 & 0.013 & 0.03 & 0.01 & 0.02 \\
\hline $300^{\circ} \mathrm{C}$ & 2.6 & 2.0 & 0.30 & 1.9 & 0.33 & 2.5 & 0.37 & 1.3 & 0.47 & 0.89 & 0.42 & 0.75 \\
\hline $400{ }^{\circ} \mathrm{C}$ & 4.6 & 3.2 & 2.9 & 3.5 & 2.2 & 8.0 & 3.0 & 3.2 & 2.7 & 6.2 & 3.5 & 7.7 \\
\hline
\end{tabular}

Table 3.

\begin{tabular}{|c|c|c|c|c|c|c|c|c|c|c|c|c|}
\hline compound & \multicolumn{2}{|c|}{ LSM00 } & \multicolumn{2}{c|}{ LSM05 } & \multicolumn{2}{c|}{ LSM15 } & \multicolumn{2}{c|}{ LSM25 } & \multicolumn{2}{c|}{ LSM35 } & \multicolumn{2}{c|}{ LSM50 } \\
\hline $\mathrm{T} /$ Gas & $\mathrm{O}_{2}$ & $\mathrm{NO}$ & $\mathrm{O}_{2}$ & $\mathrm{NO}$ & $\mathrm{O}_{2}$ & $\mathrm{NO}$ & $\mathrm{O}_{2}$ & $\mathrm{NO}$ & $\mathrm{O}_{2}$ & $\mathrm{NO}$ & $\mathrm{O}_{2}$ & $\mathrm{NO}$ \\
\hline $200^{\circ} \mathrm{C}$ & 3.4 & 86 & 0.6 & 420 & 1.3 & 150 & 3.8 & 42 & 1.3 & 11 & 1.3 & 6.6 \\
\hline
\end{tabular}




\section{Figure captions:}

Figure 1. Voltammograms recorded in either $1 \%$ nitric oxide in argon or $10 \%$ oxygen in argon with a sweep rate of $1 \mathrm{mV} / \mathrm{s}$ at $200{ }^{\circ} \mathrm{C}$ on a LSM05 cone-shaped electrode. The activity is much higher in the nitric oxide containing atmosphere than in the oxygen containing atmosphere. A large hysteresis is observed in the nitric oxide containing atmosphere in the cathodic potential region.

Figure 2. Voltammograms recorded in either $1 \%$ nitric oxide in argon or $10 \%$ oxygen in argon with a sweep rate of $1 \mathrm{mV} / \mathrm{s}$ at $300{ }^{\circ} \mathrm{C}$ on a LSM05 cone-shaped electrode. The activity is higher in the nitric oxide containing atmosphere than in the oxygen containing atmosphere. A limiting current is seen in the cathodic potential region, at approximately $-2 \mathrm{mAcm}^{-2}$.

Figure 3. Voltammograms recorded in either $1 \%$ nitric oxide in argon or $10 \%$ oxygen in argon with a sweep rate of $1 \mathrm{mV} / \mathrm{s}$ at $400{ }^{\circ} \mathrm{C}$ on a LSM05 cone-shaped electrode. The activity is almost equal in the nitric oxide and the oxygen containing atmospheres.

Figure 4. The current ratios between the current densities in the nitric oxide and oxygen containing atmospheres at $200{ }^{\circ} \mathrm{C}$. The ratios are highest for the un-substituted and low strontium substituted lanthanum manganites. The solid line is for optical guidance only. 
Figure 1.

LSM05 @ $200{ }^{\circ} \mathrm{C}$

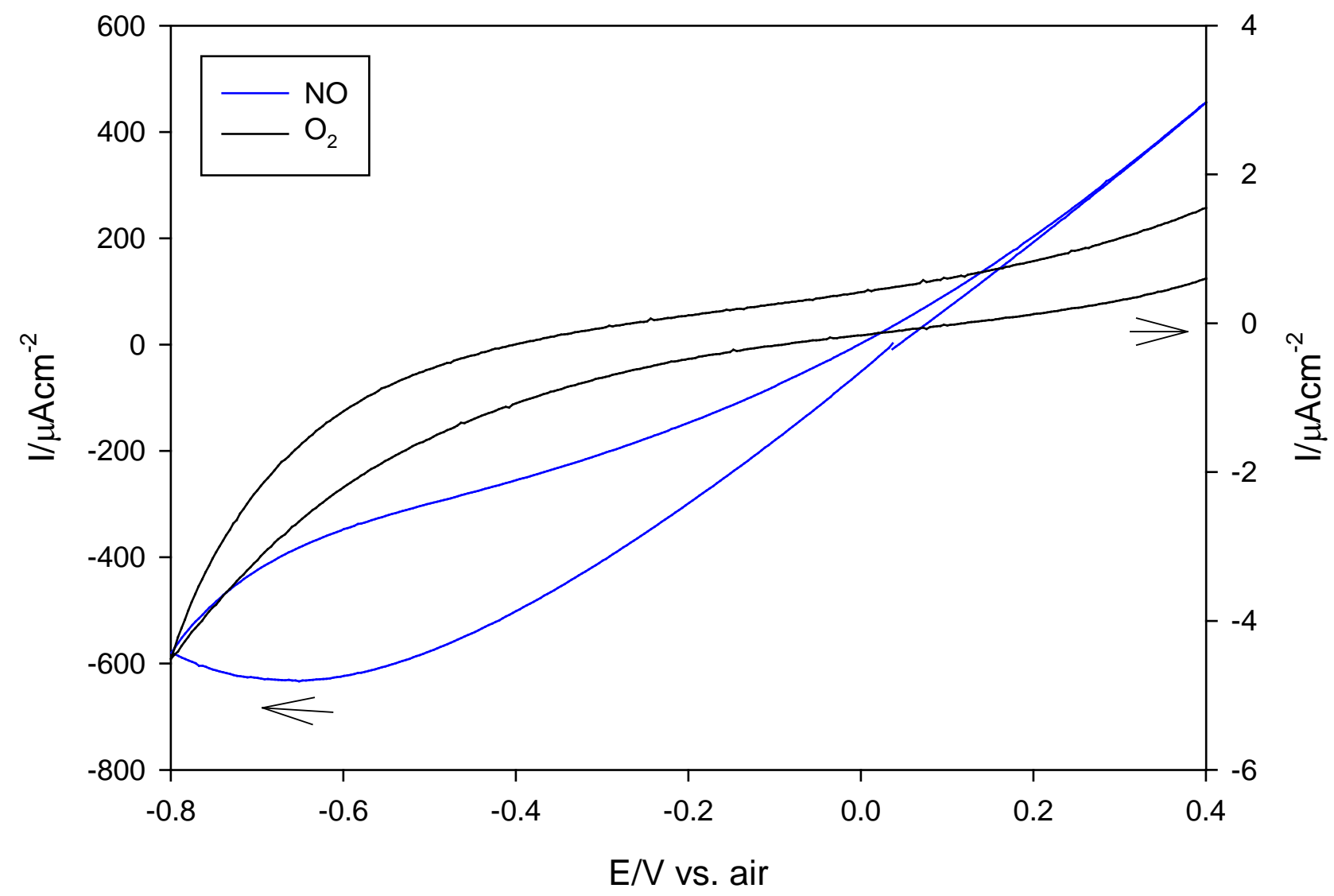


Figure 2.

LSM05 @ $300{ }^{\circ} \mathrm{C}$

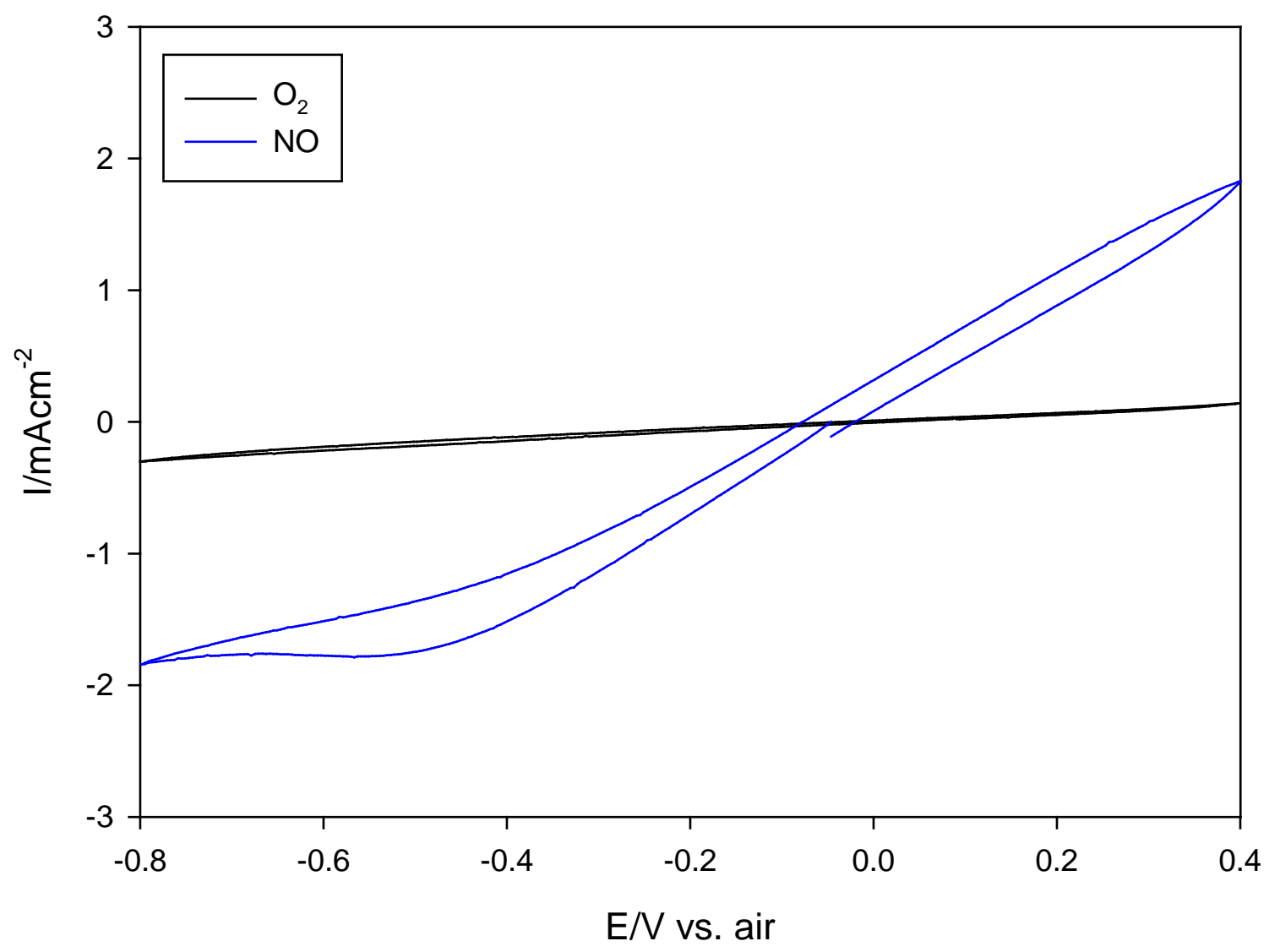


Figure 3.

LSM05 @ $400{ }^{\circ} \mathrm{C}$

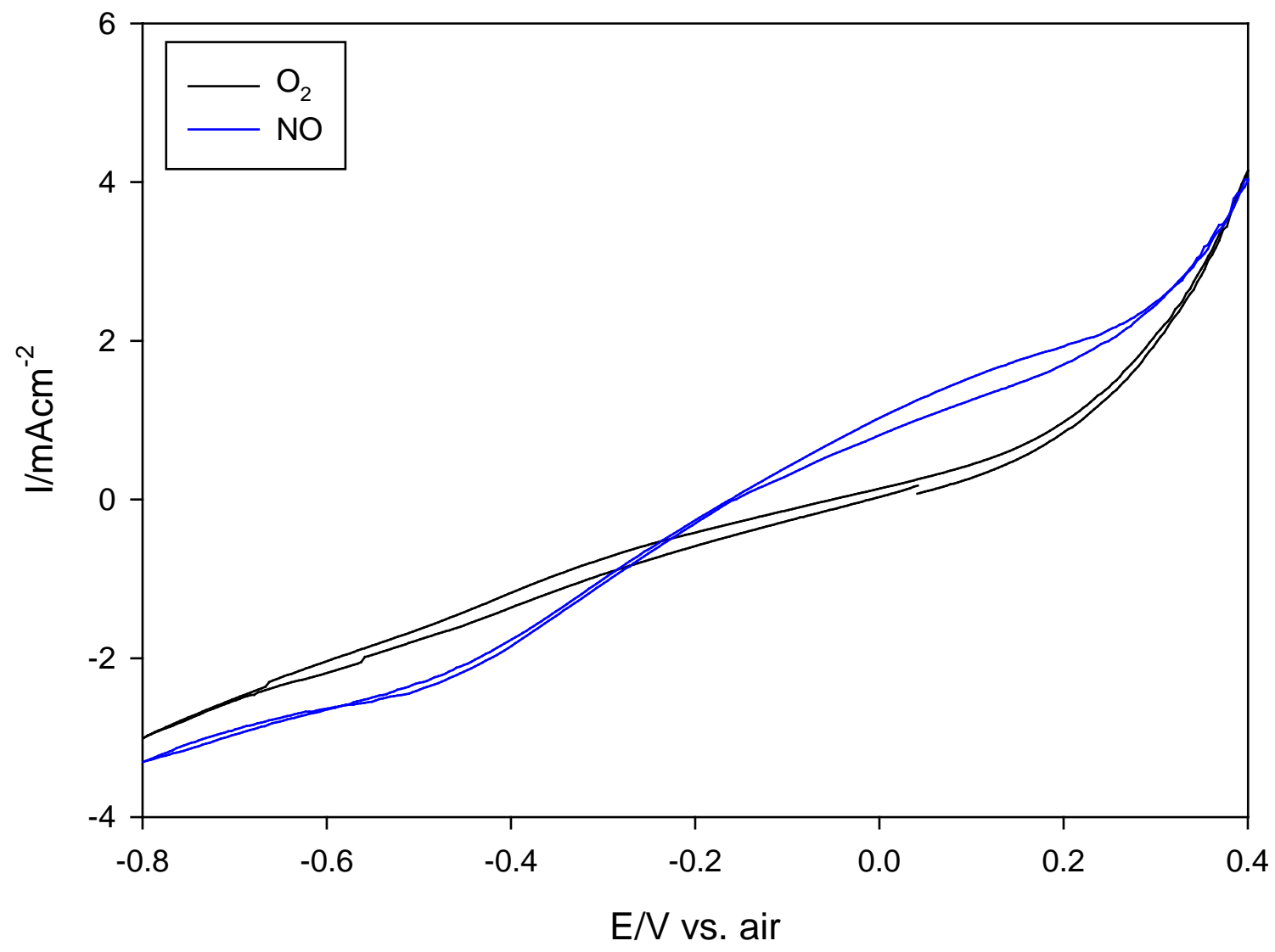


Figure 4.

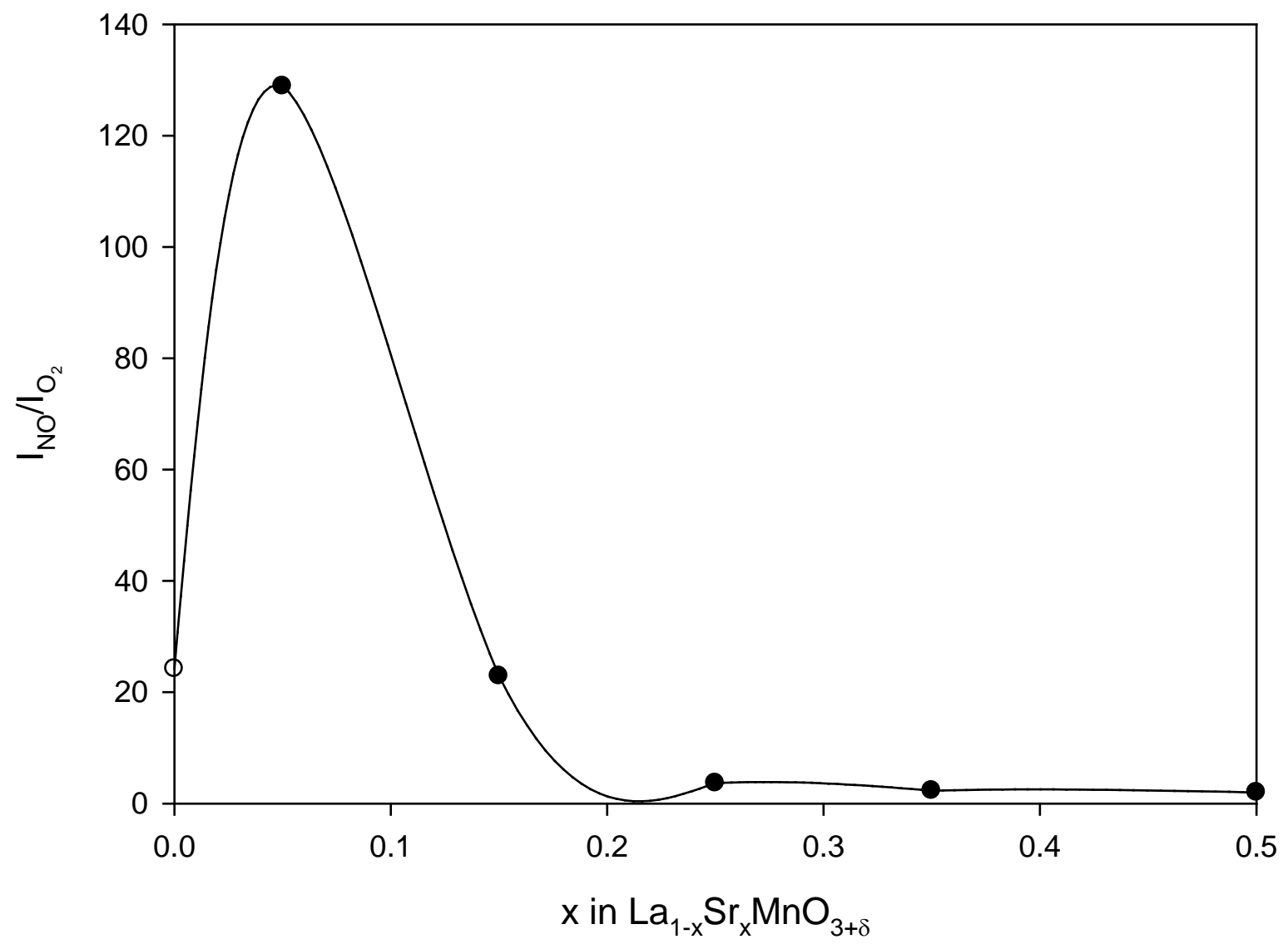

